\title{
SUBSTITUSI IPTEKS PEMBESARAN LELE TEBAR PADAT
}

\section{I.F. Nurcahyo ${ }^{1,2)}$, Yuniawan Hidayat ${ }^{1,2)}$, Venty Suryanti2, Desi Suci Handayani $^{2}$, Witri Wahyu Lestari' ${ }^{2}$, dan Edi Pramono ${ }^{2}$}

\author{
1) Pusat Pengembangan Kewirausahaan, LPPM, \\ Universitas Sebelas Maret \\ 2) Fakultas Matematika dan IPA, Universitas Sebelas Maret \\ Email: ifnurcahyo@staff.uns.ac.id
}

\begin{abstract}
ABSTRAK
Petani pembesaran lele banyak yang mengeluh gagal dalam usaha pembesaran lele. Kegagalan tersebut disebabkan oleh penggunaan pakan dan kolam yang tidak efisien serta harga pakan mahal. Tujuan kegiatan pengabdian masyarakat ini memberikan wawasan tentang metode baru dalam usaha pembesaran lele yang menguntungkan. Mitra pengabdian kegiatan ini yaitu kelompok pembesaran lele Sungut Emas di Boyolali dan petani-petani pembesaran lele disekitarnya. Metode pengabdian dilakukan dengan metode substitusi ipteks secara teori, praktek lapangan, dan pendampingan. Substitusi ipteks secara teori meliputi penjelasan tentang pembesaran lele tebar padat dan aplikasi enzim dalam efisiensi pakan. Materi praktek lapangan meliputi cara persiapan air, cara pengelolaan air, cara menangani penyakit dan cara memberi pakan. Simpulan, substitusi ipteks pembesaran lele tebar padat mampu menyelesaikan masalah yang dihadapi petani pembesaran lele tebar padat sehingga keuntungan usaha meningkat.
\end{abstract}

Kata kunci: lele, tebar padat, peluang usaha

\section{ABSTRACT}

There are a lot of farmers of catfish fattening who complain about failure of fattening catfish. The failure was caused by the use of feed and fishpond inefficiently, and the expensive price of feed. The aim of the public service activity is to provide a concept about new method of profitable business of catfish fattening. The service partner is a group of catfish fattening Sungut Emas in Boyolali and catfish farmers in surroundings. We used science and technology substitution method in theory, field practice, and assistance. Science and technology substitution in theory covers explanation about dense spread catfish fattening and enzim application in feed efficiency. The subject matters of field practice are ways of water preparation, water management, disease treatment, and feeding. The conclusion is science and technology substitution of dense spread catfish fattening can be able to solve the problems faced by the farmers, so that the profit increases.

Keywords : catfish, dense spread, business opportunities 


\section{PENDAHULUAN}

Program pengabdian masyarakat ini dilaksanakan di kelompok pembesaran lele Sungut Emas di wilayah Kecamatan Ngemplak Kabupaten Boyolali. Hampir semua petani di wilayah ini menggunakan pakan pabrikan dengan kualitas terbaik yaitu dengan kandungan protein minimal $30 \%$. Faktanya, penggunaan pakan dengan kualitas yang terbaik belum mampu menghasilkan pertumbuhan lele yang maksimal. Penggunaan pakan pabrikan yang terbaikpun petani belum mendapatkan keuntungan, bahkan banyak petani pembesaran lele yang gulung tikar dan kolamnya mangkrak.

Hal-hal yang pernah dilakukan untuk memecahkan masalah gulung tikarnya usaha pembesaran lele yaitu menggunakan pakan alternatif. Biaya pakan merupakan modal terbesar dalam usaha pembesaran lele. Penggunaan pakan alternatif diharapkan mampu menekan biaya produksi. Pakan alternatif yang pernah dicoba oleh petani Sungut Emas antara lain:

a. Pembuatan pelet sendiri.

b. Penggunaan pelet murah alternatif dari Tuban.

c. Penggunaan sinyu (campuran daging dan tulang ayam sisa produksi sosis)

Pembuatan pakan pelet sendiri pernah dilakukan. Pelet dibuat dari campuran tepung ikan, tepung roti kadaluarsa, tepung kotoran puyuh, dan tepung bulu ayam. Pelet yang dihasilkan berupa pelet tenggelam. Hasil pemakaian pakan ini yaitu lele tidak lahap, sehingga pertumbuhan lele lambat. Cara ini tidak mampu memecahkan masalah. Cara kedua yang pernah dicoba yaitu penggunaan pakan pelet yang diproduksi oleh pengusaha dari Tuban. Hasil dari percobaan ini yaitu lele tidak lahap dan pertumbuhannya lambat. Cara ketiga yaitu penggunaan sinyu sebagai pakan lele. Sinyu diperoleh dari RPA (Rumah Pemotongan Ayam) PT So Good Food Boyolali. Hasil dari pakan ini yaitu lele mau makan lahap dan pertumbuhannya sangat cepat. Akan tetapi persaingan memperoleh sinyu yang menjadi kendala.

\section{Upaya-upaya yang telah dilakukan pihak lain \\ Upaya-upaya yang} dilakukan oleh pihak lain (di luar upaya Kelompok Sungut Emas). Banyak upaya yang dilakukan oleh penggiat pembesaran lele. Upaya pertama, pembesaran lele tebar padat (1000 ekor/m2) dengan sistem boster. Sistem ini dikembangkan oleh PT Indosco Dwi Jaya Sakti. Penerapan sistem ini mengacu pada SOP yang dikeluarkan oleh PT Indosco Dwi Jaya Sakti dan menggunakan obat dan suplemen dari perusahaan tersebut. Sistem ini mempunyai 3 kunci pokok yaitu bentuk kolam yang dilengkapi drain ditengah, pakan ditambahi suplemen (yang berupa multivitamin, zat imun, dan enzim), serta pengelolaan air dengan perlakuan penambahan antiseptik, probiotik sesuai SOP (Fish Boster Centre, 2013). Menurut keterangan dari penyuluh dan sales 
perusahaan tersebut bahwa klaim terbaiknya yaitu cara ini mampu menurunkan FCR (food conversion rate) menjadi 0,7 artinya setiap 700 gram pakan dapat menghasilkan daging lele basah 1000 g. Akan tetapi tim pengabdi telah mencoba namun belum mampu menghasilkan seperti klaim tersebut.

Upaya kedua, penggunaan sistem boster yang dikembangkan tim pengabdi. Tim pengabdi menggunakan sistem boster dengan bentuk kolam yang mirip sistem boster dari PT Indosco, namun kolam dibuat lebih aerodinamis, suplemen menggunakan ramuan sendiri yang lebih murah yang berupa multivitamin dan enzim. Percobaan yang dilakukan oleh tim pengabdi hanya mampu memperoleh nilai FCR 0,9. Ditinjau dari sistem pencernaan lele, lele mempunyai usus yang pendek (Mahyuddin, 2008). Menurut tim pengusul, usus yang pendek mengakibatkan proses metabolisme tidak sempurna. Penggunaan enzim diharapkan mampu mencerna pakan diluar tubuh sehingga pakan yang masuk ke tubuh lele sudah siap serap.

Upaya yang ketiga yaitu penggunaan metode bioflok. Bioflok merupakan agregat diatom, makroalga, pelet sisa, eksoskeleton organisme mati, bakteri, protista dan invertebrata juga mengandung bakteri, fungi, protozoa dan lainlain yang berdiameter 0,1-2 $\mathrm{mm}$. Bahan-bahan organik itu merupakan pakan alami ikan dan udang yang mengandung nutrisi baik, yang mampu disandingkan dengan pakan alami, sehingga pertumbuhan akan baik bahkan jumlah pakan yang diberikan bisa diturunkan. Nafsu makan yang tinggi dan usus pendek pada ikan lele menyebabkan ikan lele mudah lapar namun cepat menyebabkan akumulasi kotoran menumpuk. Tehnik Bioflok pada intinya mereduksi bahan-bahan organik dan senyawa beracun yang terakumulasi dalam air pemeliharaan ikan. Dengan sistem self-purifikasi didapat hasil akhir meningkatkan effisiensi pemanfaatan pakan dan peningkatan kualitas air. Hasilnya adalah [1] :

a) Pakan ikan lele akan lebih efisien, pertumbuhan ikan lele akan rampag artinya selama kegiatan budidaya tidak ada kegiatan penyortiran.

b) Kecepatan pertumbuhan ikan yang lebih optimal dengan masa waktu panen yang lebih singkat.

c) Padat tebar per meter kubik yang lebih tinggi kisaran 500 1000 benih $/ \mathrm{m}^{3}$.

d) Ikan sehat dan gesit serta mengurangi penyakit pada ikan

\section{Masalah}

Masalah yang dihadapi oleh petani pembesaran lele meliputi: lahan, bentuk kolam, dan pakan (Gambar 1). Efek dari masalah yaitu keuntungan rendah, bahkan malah rugi. 


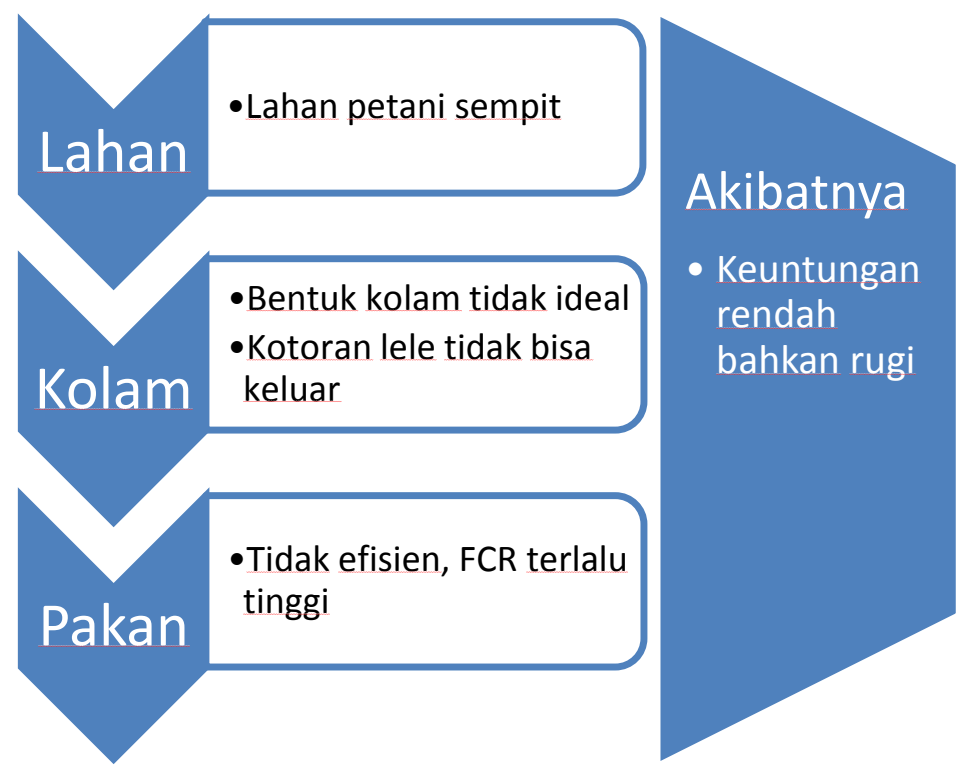

Gambar 1. Masalah yang dihadapi petani pembesaran lele

\section{Solusi}

Menurut tim solusi yang tepat dituangkan dalam skema Gambar 2.

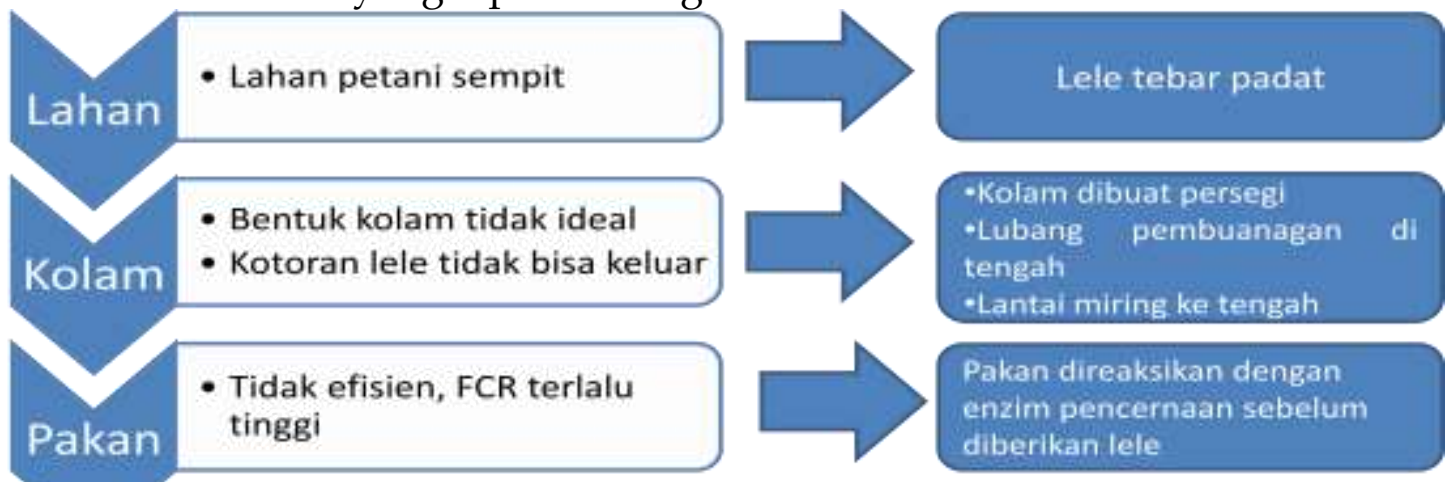

Gambar 2. Solusi yang ditawarkan

\section{METODE PENGABDIAN \\ Metode}

Pengabdian dilakukan melalui 3 tahapan, yaitu :

1. Pembuatan kolam lele tebar padat

2. Substitusi Ipteks

3. Metode substitusi ipteks meliputi secara teori, praktek lapangan, dan pendampingan. Substitusi ipteks secara teori meliputi penjelasan tentang pembesaran lele tebar padat, teknologi kolam dan aplikasi enzim dalam efisiensi pakan. Materi praktek lapangan tentang pemeliharaan

4. Pendampingan

5. Pendampingan dilakukan mulai sejak mulai persiapan kolam sampai panen.

\section{Lokasi pengabdian masyarakat}

Lokasi Pengabdian di Kelompok Tani Pembesaran lele Sungut Emas yang beralamat di Dusun Jebol, Desa Donohudan, Kec. Ngemplak, Kab. Boyolali. 


\section{Durasi Waktu}

Waktu pengabdian kurang lebih 3 bulan.

\section{HASIL DAN PEMBAHASAN}

\section{Substitusi Ipteks}

Kegiatan ini dilakukan melalui kegiatan in class dan out class. Ipteks yang disubstitusikan yaitu teknologi kolam tebar padat dan teknologi pakan dengan aditif enzim. Substitusi ipteks dijabarkan sebagai berikut:

\section{Teknologi kolam lele tebar padat}

Kolam lele tebar padat sebaiknya dibuat dengan ukuran kecil. Dari percobaan yang dilakukan oleh tim pengabdi, kolam untuk tebar padat sebaiknya bentuk penampang atas berupa bujursangkar dengan ukuran sekitar $(2 \times 2 \times 1,2) \mathrm{m}^{3}$ (Gambar 3 dan 4). Untuk ukuran sekitar $(3 \times 3 \times 1,2) \mathrm{m}^{3}$ dan lebih besar tidak dianjurkan. Alasan hal berkaitan dengan saran ukuran tersebut yaitu: a) Bila ukuran dibuat $(3 \times 3 \times 1,2)$ $\mathrm{m}^{3}$ dan ukuran lebih besar akan menyebabkan kotoran lele terlalu lama mengumpul di bak drain.

b) Ukuran kecil dibuat dengan tujuan untuk meminimalkan resiko kematian bila terjadi kematian massal.

c) Ukuran kecil dibuat agar jumlah tiap panen tidak terlalu besar, hal ini juga mempertimbangkan kemampuan pengepul dalam membeli lele.

Spesifikasi Kolam:

a) Kolam berupa tembok permanen.

b) Ukuran kolam $(2 \times 2 \times 1,2) \mathrm{m}^{3}$

c) Ukuran drain $(40 \times 40) \mathrm{cm}^{2}$, posisi di tengah

d) Bentuk pojok kolam dibuat lengkung bertujuan agar air yang dikocorkan dapat mengalir berputar ke tengah dan akan membawa kotoran keluar. 


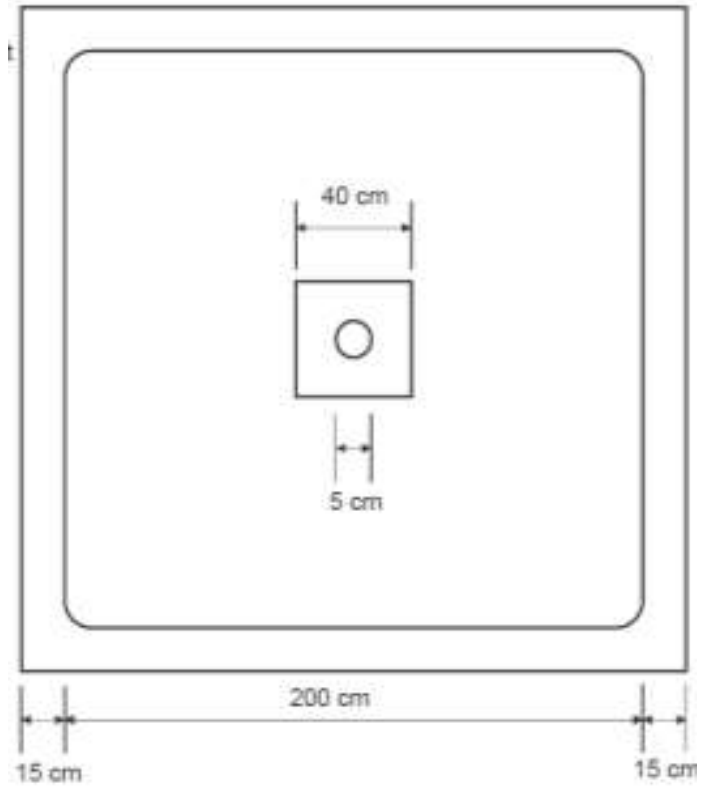

a

Gambar 3. Sketsa kolam tebar padat

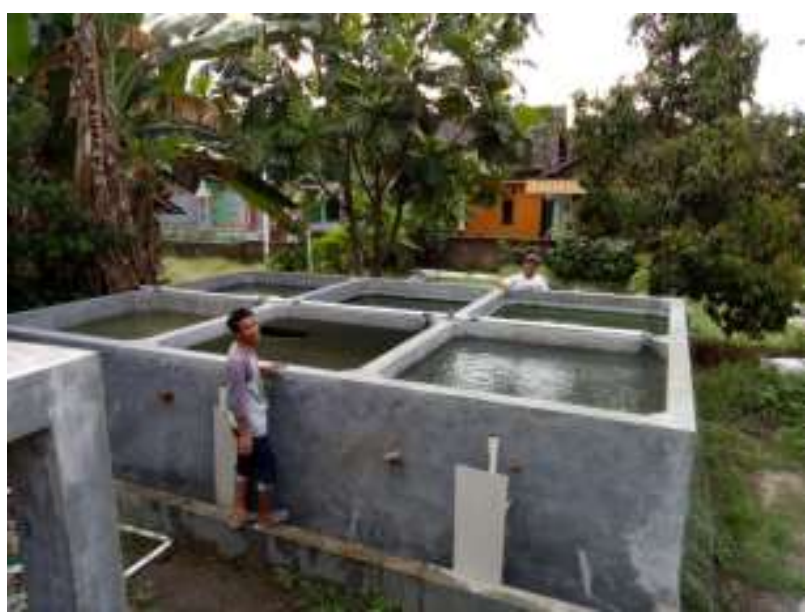

Gambar 4. Kolam tebar padat

\section{Persiapan air}

Kolam diisi air dengan ketinggian $50 \mathrm{~cm}$ dan ditambahkan dengan pupuk organik cair untuk menumbuhkan plankton. Setelah tumbuh plankton, baru mulai diisi benih lele. Lama penumbuhan plankton berkisar 10-15 hari Apabila air banyak jentik-jentik nyamuk, disarankan penaburan benih dilakukan pada hari ke 5 . Hal ini untuk antisipasi timbulnya penyakit yang disebarkan oleh nyamuk.

\section{Pakan pelet dan aditif}

Guna mendapatkan pakan yang efisien, pakan pelet ditambahkan zat aditif. Pakan pelet yang digunakan dalam usaha pembesaran ini mempunyai spesifikasi seperti yang ditunjukkan pada 
Tabel 1. Spesifikasi pakan

\begin{tabular}{|l|c|c|c|c|c|}
\hline $\begin{array}{l}\text { Umur } \\
\text { tebar } \\
(\text { hari ke-)a }\end{array}$ & $\begin{array}{c}\text { Ukuran } \\
(\mathrm{mm})\end{array}$ & Protein (\%) & $\begin{array}{c}\text { Lemak } \\
(\%)\end{array}$ & $\begin{array}{c}\text { Fiber } \\
(\%)\end{array}$ & $\begin{array}{c}\text { Kadar Air } \\
(\%)\end{array}$ \\
\hline $1-7$ & $1.3-1.7$ & $39-41$ & 5 & 6 & 10 \\
\hline $8-15$ & $2,0-2,3$ & $31-33$ & $4-6$ & $3-5$ & $9-10$ \\
\hline $16-30$ & $2,3-3,0$ & $31-33$ & $4-6$ & $3-5$ & $9-10$ \\
\hline $31-60$ & $3,2-4,0$ & $31-33$ & $4-6$ & $3-5$ & $9-10$ \\
\hline $61-p a n e n$ & 5 & $31-33$ & $4-6$ & $3-5$ & $9-10$ \\
\hline
\end{tabular}

${ }^{a}$ ukuran lele mulai ditebar yaitu $4-5 \mathrm{~cm}$

Zat aditif yang digunakan untuk mengefisienkan pakan yaitu multivitamin dan enzim pencernaan (phytase, alpha amylase, beta glucanase, cellulose, pectinase, protease, dan xylanase). Enzim pencernaan dapat diganti dengan probiotik, namum perlu fermentasi sekitar 12 jam.

\section{Pemeliharaan}

Pemberian pakan

Pakan yang diberikan $5 \%$ berat badan lele per hari. Sejumlah $5 \%$ tersebut bisa diberikan 2-3 kali sehari. Cara mencampur pakan pelet dan zat aditif yaitu zat aditif dilarutkan dalam air kemudian dicampurkan ke dalam pakan dan diaduk secara merata. Jumlah zat aditif yang digunakan sesuai dosis yang diberikan oleh pabrik pembuat zat aditif. Perbandingan volume air dan pakan sekitar 1:4.
Setelah 30 menit baru diberikan ke lele.

Perawatan air

Setiap sebelum pemberian pakan, air dikurangai sekitar $15 \mathrm{~cm}$ untuk mengeluarkan kotoran lele. Setiap 7 hari air dikurangi hingga tersisa $25 \%$ dan diberi obat antiseptik dengan tujuan untuk membunuh kuman dan penyakit. Penggunaan obat dan antiseptik dihentikan pada 15 hari sebelum panen.

Sortasi lele

Sortasi lele dilakukan saat umur 1 bulan berdasarkan ukuran. Sortasi berfungsi untuk mengurangi peluang terjadinya kanibalisme.

\section{Perhitungan sederhana laba rugi}

Perhitungan laba rugi untuk usaha pembesaran lele dengan 1 kolam ukuran $(2 \times 2 \times 1,2) \mathrm{m}^{3}$. Keperluan modal dirinci sebagai berikut:

Tabel 2. Modal tetap

\begin{tabular}{ccc}
\hline Nama & Harga (Rp) & $\begin{array}{c}\text { Harga penyusutan/periode usaha } \\
\mathbf{( R \mathbf { p } )}\end{array}$ \\
\hline Kolam & 3.500 .000 & 43.750 \\
Pompa air & 500.000 & 40.000 \\
\hline Jumlah & 4.000 .000 & 83.750 \\
\hline
\end{tabular}




\begin{tabular}{lr}
\multicolumn{2}{c}{ Tabel 3. Modal tidak tetap } \\
\hline Jenis & $\begin{array}{c}\text { Harga } \\
\text { (Rp)/periode } \\
\text { pemeliharaan }\end{array}$ \\
\hline 4000 ekor benih lele 4-5 & 520.000 \\
5 kg Pakan PF 1000 & 75.0000 \\
30 kg 781-1 & 300.000 \\
90 kg 781-2 & 870.000 \\
120 kg 781-3 & 1.120 .000 \\
120 kg 782 & 1.040 .000 \\
Multivitamin & 30.000 \\
Enzim & 100.000 \\
Listrik & 150.000 \\
Tenaga kerja per kolam & 150.000 \\
\hline \multicolumn{2}{c}{ Jumlah } \\
\hline
\end{tabular}

Asumsi harga jual per kg lele yaitu Rp 16.000,-

Setiap panen diperkirakan mendapatkan lele sebanyak $400 \mathrm{~kg}$ seharga Rp 16.000,-/kg sehingga setiap panen mendapatkan uang Rp 6.400.000,-

$$
\begin{array}{ll}
\text { Laba tiap } & =\text { harga jual/panen }-(\text { biaya penyusutan modal } \\
\text { panen } & \text { tetap/panen }+ \text { biaya tidak tetap/panen }) \\
& =(\operatorname{Rp~6.400.000,-)}-(\operatorname{Rp} 83.750+\operatorname{Rp} 5.030 .000,-) \\
= & \operatorname{Rp} 1.286 .250,-
\end{array}
$$

Jadi untuk setiap periode sehingga keuntungan usaha pemeliharaan bisa diperoleh laba meningkat.

Rp 1.286.250,-

Keuntungan tebar padat

1. Meningkatkan efisiensi kolam

2. Meningkatkan efisiensi pakan

3. Meningkatkan laba usaha

\section{KESIMPULAN}

Substitusi Ipteks pembesaran lele tebar padat mampu menyeselaikan masalah yang dihadapi petani pembesaran lele tebar padat

\section{DAFTAR PUSTAKA}

1.blogspot.co.id/2016/04/budiday a-lele-padat-tebarmenggunakan.html

Mahyuddin, Kh., 2008, Panduan Lengkap Agribisnis Lele, Penebar Swadaya, Cetakan 1, Jakarta

Fish Boster Centre, 2013, Standar Operasional Prosedur Pembesaran Ikan Lele Sistem Boster, Sidoarjo 